\title{
Development of Elementary School Islamic Religious Education Textbooks Class IV Comic Based
}

\author{
Agus Santri ${ }^{1}$, Ali Imran Sinaga ${ }^{2}$, Salim $^{2}$ \\ ${ }^{1}$ Postgraduate Program of Tarbiyah and Teacher Training Faculty, State Islamic University of North Sumatera, \\ Medan, Indonesia \\ ${ }^{2}$ Tarbiyah and Teacher Training Faculty, State Islamic University of North Sumatera, Medan, Indonesia \\ agoessantrie@gmail.com
}

\section{Abstract}

This study aims to develop a grade IV comic-based Islamic Religious Education textbook as well as to determine the level of eligibility and effectiveness of its use. Initial product development is carried out through preliminary studies in the form of needs analysis and curriculum analysis. The feasibility test was carried out by a questionnaire assessment by three experts, namely material experts, media experts, and comic experts. The effectiveness level of the product can be known through individual, group trials and field trials. The research method used is the $R$ and $D$ or research and development method, with six steps of development, starting from the initial study, initial product, expert validation, individual and group testing, and field testing to the final product. The result is a product in the form of a comic-based grade IV Islamic Religious Education elementary school textbook that is very feasible and effective. The average score for the feasibility test was $90.05 \%$ in the Very Eligible category, while the average score for the effectiveness test was $88.67 \%$ with the Effective category.
Keywords

Islamic religious education textbooks; comic

\section{Introduction}

Teaching material is very important in an educational process. Given that education itself is meaningful as a process of transfer of knowledge and transfer of values from teacher to student, teaching materials can be a media or a bridge for the process of transferring knowledge and values properly. Teaching materials become part of the learning resources for students in a learning process. Teaching materials can also help students to learn teaching materials better so that students are able to master them in their entirety. In essence, teaching materials are made or arranged in order to be a part of the process of achieving learning objectives effectively and efficiently.

The function of teaching materials in a learning process include: first; be a guideline for students, so that the learning activities they do are directed and refer to the educational goals to be achieved including the basic competencies that have been set. Second; a guide for teachers or educators so they can also provide targeted and relevant teaching with educational goals. And third; teaching materials also function as an evaluation tool, to find out the extent of the attainment of the educational goals.

One type of teaching material is textbooks, textbooks are examples of teaching materials that are printed or printed. Textbooks are written or printed material which contains instructional or scientific material that has been systematically compiled by referring to the syllabus in the applicable curriculum. Textbooks can function as a teacher's handbook with 
the aim of assisting the teacher or educator in delivering teaching materials that are in accordance with the demands of the syllabus and curriculum. Textbooks also make it easier for students to learn teaching material anytime and anywhere, they do not have to bother writing all the material to be taught because it has been printed or written in the textbook.

Teachers should be able to make textbooks that fit the needs and desires of their students. So that the textbook becomes an interesting textbook for them, so that they will be happy to read and will automatically learn the material contained in the textbook. An interesting textbook will be an external motivation for students to read so that the learning process can run better. The ability to design good and effective textbooks is part of the learning design that should be owned and mastered by the teacher.

In fact there are not many teachers who make textbooks for the subjects they teach, including Islamic Studies teachers. This can be seen by researchers for example from direct observation and question and answer to Islamic Studies teachers in Deli Serdang Regency where researchers serve, of the many Islamic Studies teachers that researchers are familiar with, only a few have made their own teaching materials. Most of the Islamic Studies teachers who make these teaching materials are Islamic Studies teachers and book authors, which means they are active teachers who take the time to produce a work, including teaching materials such as learning media and textbooks.

Textbooks can be made in another format that is somewhat different from the handbook or the main textbook, so that there are variations in the reading for students. The format can be adjusted to the needs and interests of students. Textbooks in the form of comics can be an option for Islamic Studies teachers to make textbooks, especially for students in elementary schools. Because at the age of students in elementary school is still classified as the age of children, where psychologically children will prefer reading picture books. Children are very happy to read stories and see pictures, especially reading about stories or fairy tales.

A textbook that is displayed in formats such as illustrated story lines as comic forms, should be more attractive to children, namely elementary school students, so that their interest in reading the textbooks is expected to increase. Especially if a student is involved in the work of the comic book form, it is likely that he will feel more happy and interested again to see and read the textbook later. Students can be used as characters who play a role in the comic book later.

To that end, researchers want to do a deeper study of teaching materials and textbooks, and can make a textbook for Islamic Religious Education for elementary school level. Where the textbook will be based on comic books in the hope that students will be interested in reading the book. Elementary school becomes the level that researchers choose on the grounds that the researcher himself is a religious teacher in elementary schools with ten years of teaching experience, and previously taught at Madrasah Ibtidaiyah (Islamic schools at the elementary level) for five years. Fifteen years is a time for researchers to teach at the elementary level, so that more or less researchers have mastered what material will be presented in textbooks that researchers will develop later.

\section{Research Methods}

Etymologically the word development means the process or way, the deed develops. The Law of the Republic of Indonesia Number 18 Year 2002 defines development as an action based on science and technology whose purpose is to utilize the principles and theories of science that have been proven to be correct in order to increase the functions, benefits, and 
applications of existing science and technology. or produce new technology. According to Sutopo and Soemanto (1993: 45) the word development refers to an activity carried out continuously to find ways or new products.

Setyosari (2010: 197) says that development in a general sense is a process of slow growth (evolution) and gradual change. Furthermore Setyosari (2010) explains that development means the process of interpreting or describing specifications in physical form, or in other words, development is a process for producing new products in a study. In conclusion, the notion of development in education is an effort made consciously and planned for the purpose of improving a learning model or media, so that the learning process can be done better so that the goals that are aspired can be achieved more effectively and efficiently.

Teaching material development activities are activities contained in the steps of the design of the learning model. Although the steps of each of the design development models are different and the placement of the teaching material development steps are also different, but the teaching material development activities are owned by all of the design models. This shows the importance of this activity in learning. Therefore, the teacher, as a designer in learning done in class should know, understand and apply the development of teaching materials even though it is simple. At least the teacher has a record of how and what material will be delivered to students, starting from the subject matter, sub-subject and so on.

The research entitled Development of Multicultural Based Teaching Materials in SMP 17 Medan written by Ali Imran Sinaga et al., Concluded that teaching materials produced in terms of material scored $87.5 \%$, design experts $83.62 \%$. While the field trial results obtained a value of $95.83 \%$ with a very good predicate. This shows that the developed teaching material is feasible based on expert validation test and the level of effectiveness of its use is very good, so that this product can be developed and used more widely.

Another relevant study is the second study entitled "Development of Physics Comic Material Based on Android in the Subject of Temperature and Heat in MA Class XI" by Susanti Septiana et al (2019: 208) with the conclusion that based on data obtained on the results and discussion of the development of teaching materials Android-based physics comics, it can be concluded that the validity of teaching materials in the category is very valid, so teaching materials can be used as teaching materials on the subject of temperature and heat.

The third study was by Yiyin Isgandi and Pandu Prasodjo (2018: 97). The study was titled "Development of Islamic Religious Education Textbook Based on Nationalist Character and Soul Education". Based on the stages of research and development it can be concluded that the Islamic Religious Education textbook based on nationalist character and soul education can meet the needs of prospective educator students. Especially in an effort to deradicalize religious understanding, the application of noble and ethical learning and teaching and learning, family education, and the love of the Indonesian homeland.

Textbooks are one type of teaching materials used as learning media in the teaching and learning process. In general, the types of teaching materials can be divided into four, namely printed teaching materials, listening teaching materials, instructional materials, interactive teaching materials, and teaching books are examples of printed teaching materials. Islamic Religious Education learning material certainly requires teaching materials that are appropriate to the type of material and students' needs. It is not an easy thing to make PAI teaching materials, considering that Islamic Religious Education teaching materials are related to things that are transcendental or unreachable by the senses. So, teachers must be 
clever in making appropriate teaching materials to give understanding to students properly and correctly.

Anam (2016: 71) in his article states that the thing that really needs attention is that according to its specificity, the Islamic Religious Education teaching materials are mostly philosophical abstract which is difficult to hold a scientific approach, akliyah. Educators are expected to have the ability to convey something abstract to be more concrete and easily understood by students. Anam (2016) further said that as is well known, the core points of Islamic teachings include: Aqeedah, Shari'ah and Morals. The three core teachings of Islam are then elaborated in the form of Pillars of Faith, Pillars of Islam and Morals. And out of the three, knowledge of monotheism, science of jurisprudence and moral knowledge.

The following understanding and further benefits of textbooks can be seen from the following opinions expressed by experts:

1. According to Suhardjono (2001), a textbook is a book that is used as a textbook in a particular field of study, which is a standard book prepared by experts in their fields for instructional purposes and objectives.

2. Mintowati (2003) says that textbooks are one of the means of the success of the teaching and learning process. Textbooks arranged systematically will facilitate students in the material so as to support the achievement of learning objectives.

3. Arifin's opinion (2009) that textbooks are textbooks aimed at students at a certain level, textbooks are always related to certain subjects, textbooks are standard books written for certain instructional purposes and to support a particular teaching program.

Based on some of the opinions above, it can be concluded that textbooks are learning media in the form of printed books in which there are teaching materials on certain subjects that are arranged systematically in accordance with instructional objectives contained in the applicable curriculum and used by teachers and students in a process learn how to teach.

The benefits of the existence of textbooks are as one of the teaching guidelines for teachers, while for students it can be one source of reference for learning material that suits their needs in order to achieve instructional educational goals.

Textbooks on Islamic Religious Education subjects, which means the material in the textbook is a collection of Islamic Religious Education subject material that is in accordance with the needs and policies of the Islamic Religious Education curriculum. The benefits are as one of the teacher's handbooks and a source of reference for students to help achieve the goals of Islamic religious education in schools. Teaching materials in grade IV elementary school of course the material must be in accordance with the content of the level material which the guidance is already in the 2013 curriculum. Where the material is taken and developed from the core competencies and basic competencies of class IV elementary school.

Islamic Religious Education is a process of teaching, coaching and training that is based on the teachings of Islamic Religion and is given to students who are Muslim with the aim that he has the knowledge and understanding of his religion in order to be able to behave and practice the teachings of his religion so that he becomes a man who believes and is devoted to God The Almighty (Santri, 2019: 20).

According to Daulay (2016:43) that Islamic Religious Education is education that provides knowledge of attitudes, personalities and skills of students who are Islamic-based in teaching Islam, which is implemented at least through subjects / lectures on all lines, levels, and types of education. The basis of Islamic education is the Qur'an and the Sunnah of the Prophet SAW. On these two pillars the concept of Islamic education is built. The starting point is taken from the concept of humans according to Islam. What kind of people are 
aspired by Islam. This must be reflected in the objectives (Daulay, 2014: 16). The function of Islamic Religious Education is to form Indonesian people who have faith and are devoted to Allah SWT, Almighty God and have good character and are able to maintain peace and harmony among fellow Muslims and among religious believers. Whereas the aim of Islamic Religious Education is to develop students' abilities in understanding, living and practicing Islamic religious values that harmonize their mastery in science, technology and art.

That is a little discussion about the meaning, purpose and function of Islamic religious education subjects in schools. For this purpose to be achieved, all components of learning must be optimized for use, including in the production and supply of teaching materials.

The printed teaching material in the form of books used in Islamic Religious Education subjects and the material is teaching material or basic competencies of Class IV Elementary School is the understanding of PAI elementary textbooks for Class IV. So, this grade IV PAI textbook is used by teachers and students who study PAI in Class IV Elementary School.

Class IV learning materials in Primary Schools can be seen in the 2013 curriculum component related to Core Competencies (KI) and Basic Competencies (KD). However, in general the PAI teaching materials for grade IV elementary schools that will be displayed in the PAI textbooks that will be developed are as follows: (1) Q.S. Al-Falaq, (2) Faith in God, (3) Procedure for Purification, (4) Faith To Allah's Apostle, (5) Q.S. Al-Fiil, (6) Faith in the angels of God, (7) Reading and Movement Prayer, (8) Story of Wali Songo.

Comics are often interpreted as picture stories or pictures that tell stories and are identical to the existence of speech bubbles between the characters in them and can cause pleasure for those who read them because the stories are supported by interesting and generally colorful pictures. Understanding comics is more than just a light and entertaining picture story. Scout McCloud (2001: 9) argues that comics can mean images and other symbols that are juxtaposed (close together, next to each other) in a certain order, to convey information and / or achieve aesthetic responses from readers. Comics are a form of visual communication media that has the power to convey information in a popular and easy to understand way. This is possible because comics combine the power of images and writing, which are arranged in a storyline, making images more easily absorbed information (Waluyanto, 2005: 51).

The advantages possessed by comics can be seen from the way they are presented which contains strong visual and story elements. Visualized expression makes the reader emotionally involved so that it keeps the reader reading through to the end (Daryanto, 2013: 128). Besides the advantages of comics are:

1. The language used is everyday language, so students can quickly understand the contents of comics;

2. The use of pictures that can clarify the words of the story in the comic;

3. The use of attractive and bright colors so students will be more motivated to read comics;

4. Comics have a story that is very closely related to the events experienced by students everyday, so that they will better understand the problems they are experiencing.

However, in addition to strengths there are also weaknesses that comics have, namely comics as visual or graphic media will not look effective if used to students who cannot learn with visual or graphic media, because each student has their own style of learning. This can be minimized by having mandatory textbooks and other textbooks, and teachers must also provide assistance and teaching about teaching material, not only making Islamic Religious Education textbooks for grade IV as the only textbooks used. 
The teacher must continue to innovate in carrying out the teaching and learning process. Both in terms of methods and in terms of teaching materials or learning media. Making comic-based textbooks is expected to be an innovation that can be carried out by Islamic Religious Education teachers in schools. Innovation itself can be interpreted as making something new or improving something that already exists in order to become better, effective and efficient.

Etymologically the word innovation comes from English namely innovation which means everything that is new or renewal (Ananda and Amiruddin, 2017: 1). Innovation means new discoveries that are different from those that already exist or that have been known before (ideas, methods, or tools) (Syafaruddin et al, 2012: 23).

Furthermore, in terminology, Ananda and Amiruddin (2017: 2) understand that "innovation is an idea, thing, event, method that is felt or observed as a new one from a person or group of people (society) as a result of the invention or discourse used. to achieve certain goals or to solve problems. "

The process of educational innovation is a series of activities carried out by individuals or organizations, starting to realize the existence of innovation to implement (the implementation of educational innovations (Sutirna, 2018: 72). Implementation of educational innovations based on certain reasons. As Hasbullah (2006: 191) formulates, things which demanded the holding of educational innovations in Indonesia including: tools for the development of science and technology, population growth, increasing the amino of the community to obtain better education, demanding quality education, lack of relevance between education and community needs and the ineffectiveness of effective organizations.

Comic-based Islamic Religious Education teaching materials can be said as an innovation created through a study called research and development, with six steps of development, starting from initial studies, initial products, expert validation, individual and group tests, and field tests to the final product.

\section{Research Method}

The research method used is the R\&D or research and development method with six development steps, starting from the initial study, initial product, expert validation, individual and group testing, and field testing to the final product. This type of research is used to produce a product of research results. The resulting product will go through expert validation to find out the level of feasibility of product use as well as through field trials to determine the effectiveness level of product use. The products produced from this research are hardware products in the form of comics-based elementary school PAI grade IV textbooks.

\section{Discussion}

Final product development is carried out after going through various stages of improvement. Starting from the analysis or initial study stage by observation, interview, and curriculum analysis. Analysis of teacher and student needs for PAI elementary teaching materials. Then formed the initial product that researchers developed since the beginning of semester I of the 2019/2020 school year.

The initial product was validated by three experts, namely material expert, media expert, and comic expert. Expert validation was carried out to determine the feasibility of comics-based grade IV Islamic Religious Education textbooks. Revisions are made after 
going through that stage. Then enter the trial phase, namely individual, group, and field trials. The purpose of conducting the trial is to determine the feasibility of the product. Revisions made to improvements. So that finally the final product of the fourth grade Islamic Religious Education elementary school comic-based textbooks is formed.

Validation from media experts produced a score of 71 , with a total score of 80 , the results of the analysis of the score calculation resulted in a figure of $88.75 \%$, which means that comic-based elementary school grade IV PAI textbooks are included in the Very Eligible category. Without any revisions suggested by experts in terms of material that must be done by researchers.

Validation from media experts resulted in a score of 53, with a total score of 60 , if calculated it would produce a value of $88.33 \%$, which means comic-based elementary school grade IV Islamic Religious Education textbooks are in the Very Eligible category with some entries that researchers received from media experts and will follow up researchers.

Validation from comic experts resulted in a score of 67, with a total score of 72 , the results of the analysis of the comic expert's score calculation results showed $93.06 \%$, which means that comic-based elementary school grade IV Islamic Religious Education textbooks are included in the Very Eligible category.

The feasibility test of the comic-based grade IV Islamic Religious Education elementary textbook was assessed based on the results of the assessment questionnaire score given by the experts, namely material experts, design experts and comic experts resulting in the following scores: (1) material experts gave an assessment score of $88.75 \%$, (2) media experts gave a score of $88.33 \%$, while (3) comic experts gave a score of $93.06 \%$. After adding up and averaging, it produces a score of $90.05 \%$, which means that experts who validate comic-based grade IV Islamic Religious Education textbooks grade IV assess their worthiness with the title Very Eligible.

The results of the assessment of individual students' tests on comics-based elementary school PAI grade IV with an average score of 71.33 with a percentage of $89.17 \%$, the score shows that the comics-based elementary school Islamic Religious Education fourth grade IV is included in the very feasible category.

While the group test gave an average score of 79.75 and a presentation of $99.69 \%$ with the Very Eligible category. The average N-Gain score is 0.77 with a percentage of $77.14 \%$. Because the percentage score exceeds $76 \%$, it can be concluded that the grade IV comicbased PAI textbooks have an effective category interpretation.

The effectiveness of comic-based grade IV Islamic Religious Education textbooks is obtained through individual, group and field trials. All three trials have been completed and scores have been obtained from all three. Individual trials (3 students) resulted in a value of $89.17 \%$ with the Very Eligible product category. While the group trial results of $99.69 \%$ with the Very Eligible category and the results of the field trials resulted in a product value of $77.14 \%$ which was included in the Effective category. The average assessment of the results of the above trials shows that the average calculation in the three trials conducted on the product produces a value of $88.67 \%$. It can be concluded that in terms of effectiveness, the use of comics-based grade IV Islamic Religious Education textbooks is included in the Effective category. 


\section{Conclusion}

The development of grade 4 Islamic Religious Education elementary school textbooks was developed based on basic competencies in the 2013 curriculum which included 8 materials / titles. The results of the questionnaire assessment for the cumulative feasibility test obtained an average score of $90.05 \%$ with the category Very Eligible. While the level of effectiveness of comic-based grade IV Islamic Religious Education textbooks obtained an average score of $88.67 \%$. This score is greater than $76 \%$, which means the textbook developed is effective.

Suggestions that can be delivered related to the use of comic based Islamic Religious Education elementary school textbook products is that this grade IV comic based elementary Islamic Religious Education textbook is not the only textbook that can be used as a source of Islamic Religious Education learning. Therefore, researchers suggest to users to be able to take advantage of various other learning resources, especially textbooks from schools. Schools are expected to complete more complete Islamic Religious Education learning resources in the school library and also provide internet access for students to use as online learning resources. Islamic Religious Education teachers who want to develop comic-based Islamic Religious Education textbooks can use their own student pictures, so that the resulting textbooks can be more attractive to their students.

\section{References}

Ananda, Rusydi dan Amiruddin (Ed). Inovasi Pendidikan; Melekitkan Potensi Teknologi dan Inovasi Pendidikan. Medan: CV Widya Puspita. 2019.

Anam, Choirul. Pengembangan Bahan Ajar Paidengan Model Pendidikan Berparadigma Profetik. Al Ta'dib Volume 6 No. 1, Juli 2016.

Arifin, Z. Evaluasi Pembelajaran. Bandung: Remaja Rosdakarya. 2009.

Daryanto. Media Pembelajaran Peranannya Sangat Penting Dalam Mencapai Tujuan Pembelaaran. Yogyakarta: Gava Media. 2013.

Daulay, Haidar Putra. Pemberdayaan Pendidikan Agama Islam di Sekolah. Jakarta: Kencana. 2016.

Daulay, Haidar Putra. Pendidikan Islam dalam Perspektif Filsafat. Jakarta: Prenadamedia Group. 2014.

Hasbullah. Otonomi Pendidikan; Otonomi Daerah dan Implikasinya Terhadap Penyelenggaraan Pendidikan. Jakarta: PT Raja Grafindo Persada. 2006.

Imran, Ali Sinaga, dkk. Pengembangan Bahan Ajar Berbasis Multikultural di SMP 17 Medan. Jurnal Edu Religia, Volume 2, No. 1 Januari - Maret 2018.

Isgandi, Yiyin dan Pandu Prasodjo. Pengembangan Buku Ajar Pendidikan Agama Islam Berbasis Pendidikan Karakter Dan Jiwa Nasionalis. Indonesia Journal Of Islamic Education - vol. 5 no. 2. 2018.

McCloud, Scout. Understanding Comic. Jakarta: Kepustakaan Populer Gramedia. 2001.

Mintowati. Panduan Penulisan Buku Ajar. Jakarta: Depdikbud. 2003.

Santri, Agus. PAI di Sekolah. Jombang: Kertasentuh. 2019.

Setyosari, Punaji. Metode Penelitian dan Pengambangan. Jakarta: Kencana. 2010.

Septiana, Susanti dkk. Pegembangan Bahan Ajar Komik Fisika Berbasis Android Pada Pokok Bahasan Suhu Dan Kalor Di MA Kelas XI. Jurnal Pembelajaran Fisika, Vol. 8 No. 3, September 2019. 
Suhrdjono. Buku Ajar Ilmu Penyakit Dalam Jilid II, edisi ketiga. Jakarta: FK UI. 2000.

Sutirna. Inovasi dan Teknologi Pembelajaran. Yogyakarta: Deepublish. 2018.

Sutopo, Hendayat dan Westy Soemanto. Pembinaan dan Pengembangan Kurikulum Sebagai Substansi Problem Administrasi Pendidikan. Jakarta: Bumi Aksara. 1993.

Syafaruddin dkk. Inovasi Pendidikan. Medan: Perdana Publishing. 2012.

Waluyanto, Heru Dwi. Komik Sebagai Media Komunikasi Visual Pembelajaran. Jurnal Nirmana vol. 7, no. 1, Januari 2005. 